\title{
THE GENUS CORYBAS IN VIETNAM, WITH TWO NEW RECORDS
}

\author{
Vuong Ba Truong ${ }^{1}$, Van Canh Nguyen ${ }^{2}$, Paul Ormerod $^{3}$, Quang Cuong Truong ${ }^{4}$, \\ VAn TAN $\mathrm{CHU}^{5}$ \& Pankaj KumaR ${ }^{6,7}$ \\ ${ }^{1}$ Institute of Tropical Biology, Vietnam Academy of Science and Technology, 85 Tran Quoc Toan, \\ Dist.3, Ho Chi Minh City, Vietnam \\ ${ }^{2}$ Institute of Applied Technology, Thu Dau Mot University, No. 6 Tran Van On Street, Phu Hoa Ward, \\ Thu Dau Mot City, Binh Duong Province, Vietnam \\ ${ }^{3}$ P.O. Box 8210, Cairns 4870, Queensland, Australia \\ ${ }^{4}$ Bidoup, Nui Ba National Park, 5e Tran Hung Dao, Da Lat, Lâm Đồng Province, Vietnam \\ ${ }^{5}$ Center for Rescue and Conservation of Organism, Sa Pa District, Lao Cai Province, Vietnam \\ ${ }^{6}$ Kadoorie Farm and Botanic Garden, Lam Kam Road, Lam Tsuen, Tai Po, New Territories, \\ Hong Kong S.A.R., P. R. China \\ ${ }^{7}$ Author for correspondence: pkumar@kfbg.org
}

\begin{abstract}
An overview of the orchid genus Corybas in Vietnam is presented. It was known to be represented by a single species, $C$. annamensis. In this article, we report two new records, $C$. himalaicus, and $C$. geminigibbus. Detailed descriptions, synonyms, type data, information on ecology and phenology, distribution and color plates are provided for all three species along with the key to their identification.
\end{abstract}

KeY Words: Corybas annamensis, Corybas geminigibbus, Corybas himalaicus, Orchidaceae, Orchidoideae

The genus Corybas Salisb. (Salisbury 1807) comprises about 120 terrestrial and lithophytic orchid species, widely distributed in India, South China, Taiwan, Thailand, Vietnam, the Malesian region, Australia, New Zealand and the western Pacific (Pridgeon et al. 2001, Chung \& Hsu 2008, Chantanaorrapint \& Chantanaorrapint 2016, Govaerts et al. 2019). All species of this genus are small plants with underground tubers bearing single cordate leaf and a solitary flower with a pair of spurs at the base of the labellum.

This genus was first included in the orchid flora of Vietnam, in 2007 with the discovery of Corybas annamensis Aver. (Averyanov et al. 2007). Recently, from separate surveys in Fansipan Mountain and Chu
$\mathrm{Mu}$ Mountain, two more species of Corybas have been discovered. Based on available literature and consultation of herbarium specimens at K, P, LE, these two species were identified as C. geminigibbus J.J.Sm. and C. himalaicus (King \& Pantl.) Schltr. and these are hitherto new records for the orchid flora of Vietnam. Detailed description, synonyms, type data, information on ecology and phenology, distribution and color photographs are provided for all three species along with the key to identification of these species. Voucher specimens were collected and preserved in $70 \%$ ethanol and stored at VNM. Photographs were taken with a Canon 600D fitted with an EF-S 60mm f/2.8 Macro USM lens. Terminology for the morphological description follows Beentje (2012).

\section{Key to the Species of Corybas in Vietnam}

$1^{\prime}$ Spurs of labellum poorly developed or very short $(<2 \mathrm{~mm}$ long); apical part of the labellum irregularly fimbriate

C. geminigibbus

1" Spurs well developed ( $>3 \mathrm{~mm}$ long), horn-shaped; labellum apex acute, straight or slightly curved 2

2 ' Margin of labellum ciliate in apical part and erose at base, without swollen callus at mouth of throat

C. annamensis

2" Margin of labellum dentate in apical part and entire at the base, swollen callus at mouth of throat present

C. himalaicus 


\section{TAXONOMIC TREATMENT}

Corybas annamensis Aver. OrchideenJ. 14: 97. 2007 (Fig. 1).

TYPE: Vietnam. Lam Dong Province: Lac Duong District, Da Chais Municipality, elevation $1600 \mathrm{~m}$, 19 October 2005, T.T.T.Tramg, T.V.Thao, N.T.Vinh, HLF 5317 (LE01059678-Holotype!).

Small, terrestrial herbs with underground tubers. Tubers spherical, up to $7 \mathrm{~mm}$ in diameter, warty, covered with short hairs. Stem erect, terete, 2.5-4.5 $\mathrm{mm}$ long, $1.0-2.5 \mathrm{~mm}$ wide, tinged green to white; with a sheathing bract $0.8-1.2 \mathrm{~cm}$ long, $0.2-0.3 \mathrm{~mm}$ wide, finely haired at the base. Leaf solitary, sessile, cordate, surface slightly plicate, $1.5-3.5 \mathrm{~cm}$ long, $1.0-2.8 \mathrm{~mm}$ wide, membranous, dull greyish-green, irregularly wavy at the margin, apex acute. Inflorescence terminal, single flowered. Flower $1.2-1.6 \mathrm{~cm}$ in diameter, dorsal sepal dark crimson-red to purple, lateral sepals and petals white tinged with crimson towards the base, labellum white with red stripes and red margin. Dorsal sepal ovate or spathulate, emerging from the narrow base, strongly bend upwards, $2.0-2.5 \mathrm{~cm}$ long, $0.8-$ $1.2 \mathrm{~cm}$ wide, with around 11 white stripes, sepals along with labellum forming a helmet like structure. Lateral sepals filiform, free, erect, $5.0-5.5 \mathrm{~cm}$ long, $0.8-1.0$ $\mathrm{mm}$ wide. Petals similar to lateral sepals in shape, size. Labellum immobile, ovate, inconspicuously 3-lobed, 1.6-2.2 cm long, 1.4-1.8 cm wide, concave, arcuate, bent downwards, apex acute, surface finely warty, with hairs on the margin, surrounding the column towards the base, white with crimson-purple margin and 3-5 dark crimson-purple longitudinal bands on the lateral lobes and towards the margin, spur $0.4-0.6 \mathrm{~cm}$ long. Column short, 3-4 mm long, 2.0-2.5 mm wide, erect at the tip, with protruding round wings. Pollinia 4 in 2 pairs. Pedicel slender, gradually extending up to 12 $\mathrm{cm}$ during fruit maturity. Capsule ovate to cylindric, $1.0-1.5 \mathrm{~cm}$ long, $0.4-0.6 \mathrm{~cm}$ wide.

ECOLOGY AND PHENOLOGY: This species was found growing at around $1400-1600 \mathrm{~m}$ in elevation in primary humid broad-leaved evergreen montane forest. Very rare.

Flowering: June-July.

Distribution: Endemic to Vietnam (Bi Doup-Nui Ba National Park).
Specimen examined: Bidoup National Park, Da Chais Commune, Lac Duong District, Lam Dong Province, Truong Ba Vuong, Truong Quang Cuong, 2 August 2018, BV 382 (VNM 00023640) (VNM!).

Corybas himalaicus (King \& Pantl.) Schltr., Repert. Spec. Nov. Regni Veg. 19: 19. 1923; Pearce \& Cribb, Orch. Bhutan 118-120. 2002. $\equiv$ Corysanthes himalaica King \& Pantl., J. Asiat. Soc. Bengal, Pt. 2, Nat. Hist. 65: 128. 1896. $\equiv$ Calcearia himalaica (King \& Pantl.) M.A.Clem. \& D.L.Jones, Orchadian 13: 444. 2002. (Fig. 2).

TYPE: India. Sikkim: Pantling 385 (CAL-Holotype); K000859038, K000859039, K000859040 (K-Isotypes!); P00372553 (P-Isotypes!); (BM000958057, BM000032565 (BM-Isotypes!).

Small, terrestrial or lithophyte herbs with underground tubers. Tuber ovoid, ca. $2-5 \mathrm{~mm}$ in diameter. Stem erect, terete, $c a$. 5-40 mm long, divided into 2 parts, separate by a node covered by a sheath $c a .2 .5 \mathrm{~mm}$ long, tubular, basal part of stem with white papillose hairs, stem glabrous above the sheath. Leaf sessile, cordate, ca. 72-12 mm long, 8-11 mm wide, apex mucronate. Inflorescence terminal, single flowered, floral bract 4-5 mm long, $1.0-1.4 \mathrm{~mm}$ wide, apex acuminate, as long as or slightly longer than ovary and pedicel; pedicel (with ovary) ca. 4.7$5.0 \mathrm{~mm}$ long. Flower dorsal sepal reddish-white at base, petals and lateral sepals reddish-white at base, labellum white with red to dark red spots. Dorsal sepal hooded, oblanceolate, $c a \cdot 1.0-1.5 \mathrm{~cm}$ long 0.4-0.5 mm wide, clasping the basal part of labellum, margin entire. Lateral sepals filiform, connate at base $c a .5 \mathrm{~mm}$ long. Petals similar to lateral sepals, slightly longer than lateral sepals, $c a .6 \mathrm{~mm}$ long, connate with lateral sepals at base. Labellum margin inrolled forming a tubular basal, curving downward, ca. $4 \mathrm{~mm}$ long; apical part extended, 3.2-3.5 mm long, $c a .7 \mathrm{~mm}$ wide, orbicular (flattened) in outline shape; disc with reddish white callus, in front of callus dark crimson papillose; margin erose, irregular dentate only at apical part, basal two spurs at base of labellum, ca. $2.2 \mathrm{~mm}$ long, $1 \mathrm{~mm}$ wide, apex obtuse, pointing forward. Column winged at apex ca. $2.5 \mathrm{~mm}$ long. Pollinia 4 in 2 pairs. Capsule not seen. 


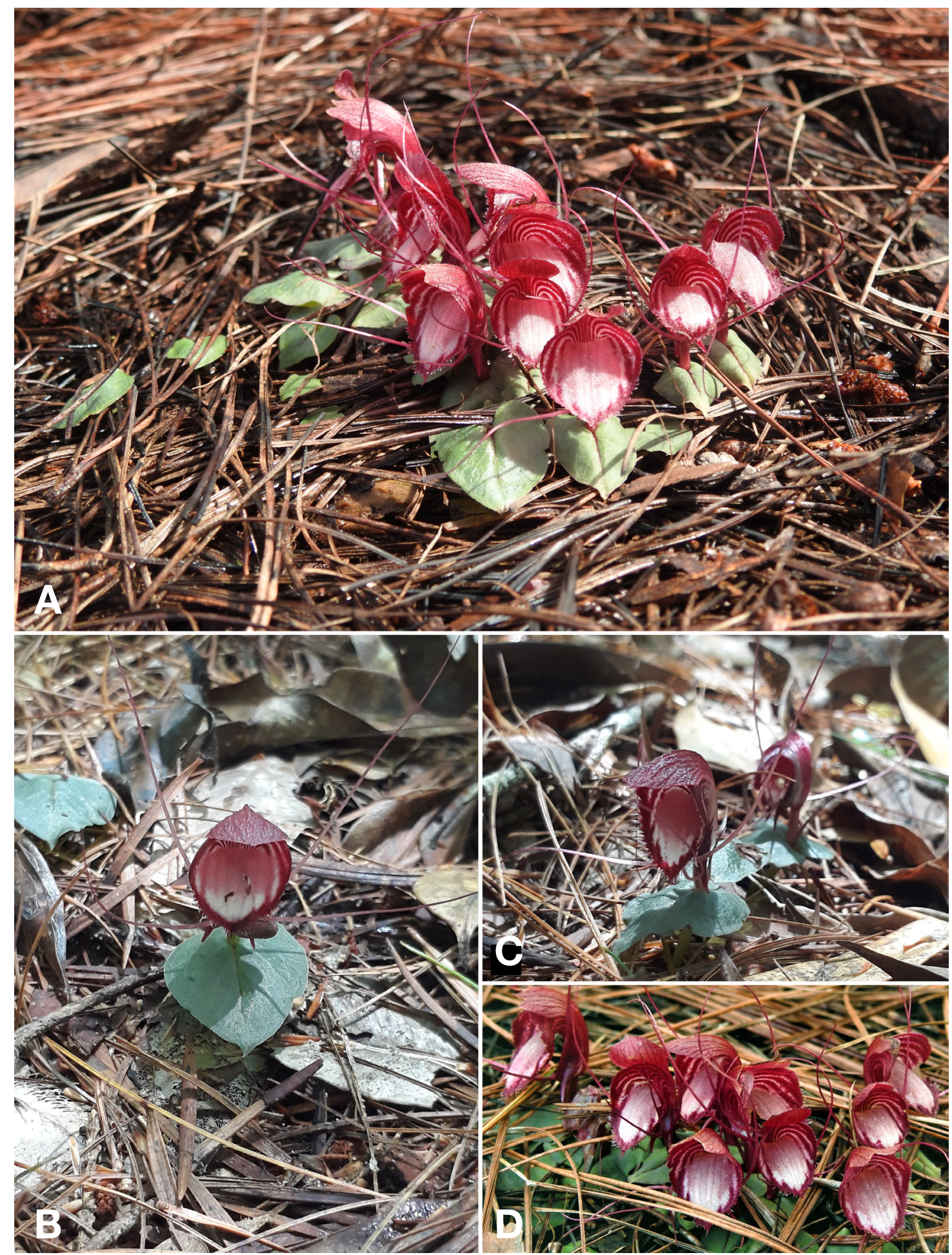

Figure 1. Corybas annamensis Aver. A-D. Plants in habitat showing morphological characters. Photographs by Nguyen Van Canh. 


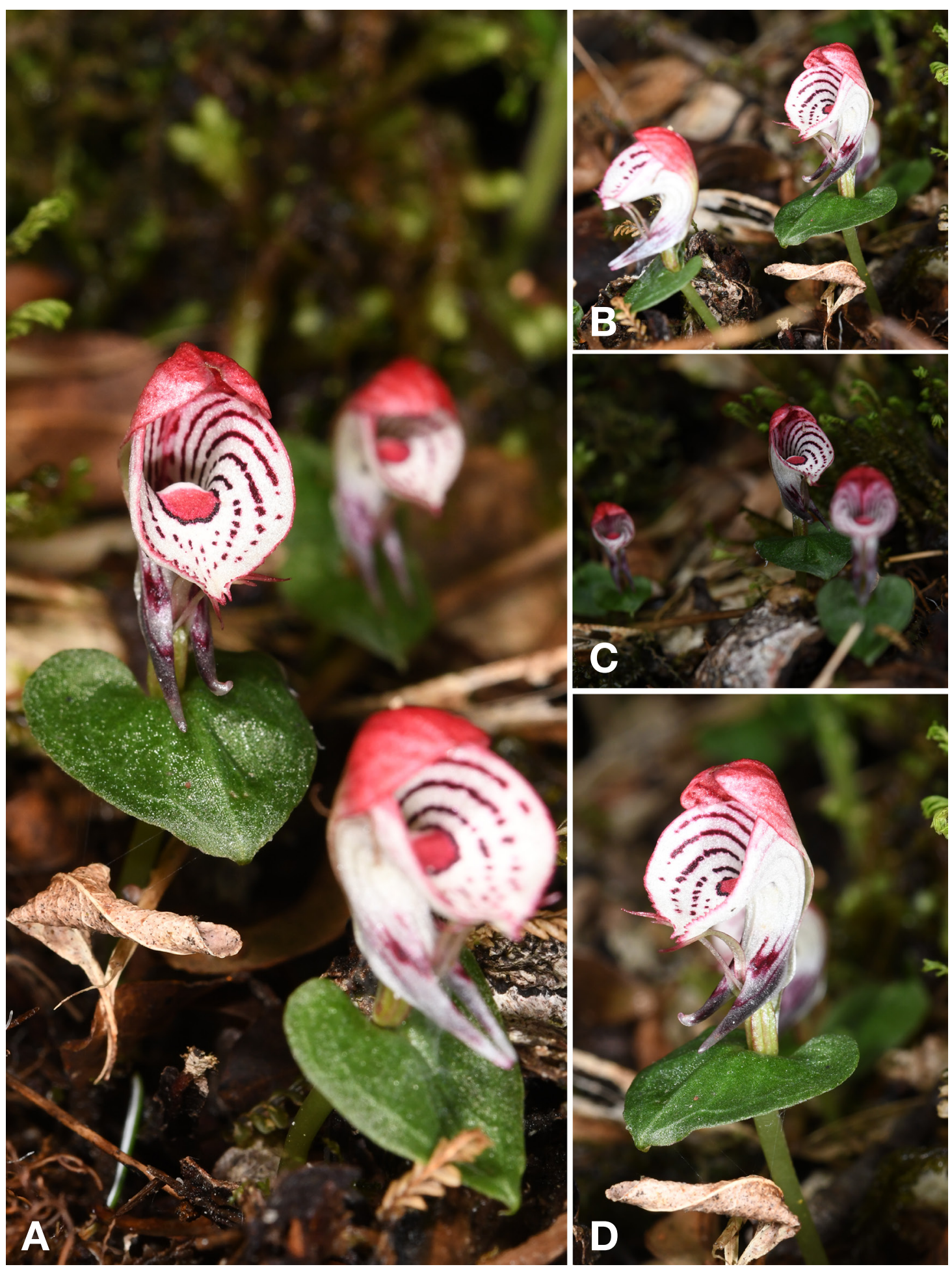

Figure 2. Corybas himalaicus (King \& Pantl.) Schltr. A-D. Plants in habitat showing morphological floral characters. Photographs by Nguyen Thanh Luan. 
Ecology And PHENOLOGY: This species was found growing as a lithophyte among mosses around 2500 $\mathrm{m}$ a.s.l. in primary evergreen mixed broadleavedconiferous forest, with Abies delavayi subsp. fansipanensis (Q.P.Xiang, L.K.Fu \& Nan Li) Rushforth as the dominant tree species. Very rare.

Flowering: June.

Distribution: Vietnam (Fansipan Mountain), Bhutan, India (Sikkim) and China (Taiwan).

Specimen examined: Lao Cai Province, Sapa Pistrict, Fansipan Mountain, Truong $\mathrm{Ba}$ Vuong, Nguyen Thanh Luan, 22 June 2019, BV 381 (VNM 00023641) (VNM!); Lao Cai Province, Sapa District, Fansipan Mountain, Truong Ba Vuong, Nguyen Thanh Luan, 23 June 2019, LE 01066674 (LE!), LE 01061397 (LE!)

NotE: The Vietnamese specimens slightly differ from the type in somewhat shorter lateral sepals and petals.

Corybas geminigibbus J.J.Sm., Mitt. Inst. Bot. Hamburg 7: 13. 1927; Dransfield et al.: 593. 1986; Seidenfaden \& Wood: 121. 1992. (Fig. 3).

TYPE: Indonesia. Borneo: West Kalimantan, Mt Mulu, Winkler 496 (HBG500940) (HBG-Holotype).

Small, terrestrial or lithophyte herbs with underground tubers. Tuber ovoid, ca. $2-5 \mathrm{~mm}$ in diameter. Stem short, erect, pale green, $c a .6 \mathrm{~mm}$, basal part covered by a tubular sheath with acuminate apex clasping the stem, $c a .3 \mathrm{~mm}$ long, with white papillose hairs at base. Leaf single, green with white markings on adaxial surface, green to pale red on abaxial, sessile, broadly ovate to cordate, $c a$. 10-12 mm long, $7 \mathrm{~mm}$ wide (at widest part), apex shortly acuminate. Inflorescence terminal, single flowered, floral bract pale green $c a$. 3-4 mm long, apex acuminate; pedicel (with ovary) ca. $3 \mathrm{~mm}$ long. Flower ca. $6 \mathrm{~mm}$ in diameter, dorsal sepal white at base and dark purple in apical part, lateral sepals and petals whitish with dark purple, labellum white with dark purple marks towards margin. Dorsal sepal hooded, strongly curved downward, oblanceolate, $c a$. $8.0-8.5 \mathrm{~mm}$ long, $3 \mathrm{~mm}$ wide, apex mucronate. Lateral sepals free, filiform, ca. 15-17 mm long. Petals similar to lateral sepals but shorter, ca. $11 \mathrm{~mm}$ long. Labellum margin inrolled forming a tubular basal part, curving downward $c a$. $4 \mathrm{~mm}$ long; apical part expended $c a .7 \mathrm{~mm}$ long, $6 \mathrm{~mm}$ wide (at the widest point), margin irregularly fimbriate-ciliate; apex acute or retuse; spur 2, small, ca. $1.5-2.0 \mathrm{~mm}$ long, poorly developed, broad, apex rounded. Column short, $c a .1 \mathrm{~mm}$ long, shortly winged at apical part. Pollinia 4, in 2 pairs. Capsule ellipsoid, ca. $6 \mathrm{~mm}$ long.

ECOLOGY AND PHENOLOGY: Lithophyte, associated with mosses, at around 1800-1900 $\mathrm{m}$ a.s.l. in $\mathrm{Chu} \mathrm{Mu}$ mountain, and at 1400-1500 m a.s.l. in Bidoup-Nui Ba National Park. Very rare.

FLOWERING: July.

Distribution: Vietnam (Vong Phu and Bidoup-Nui Ba National Park), Thailand (Nakhon Si Thammarat-Khao Ramrom Mountain), Peninsular Malaysia (Kedah), Indonesia (Borneo), Philippines (Palawan).

SPecimens eXAmined: Dak Lak province, M'Drak Disctrict, $\mathrm{Cu}$ Mroa Commune, Chu $\mathrm{Mu}$ Moutain, Truong Ba Vuong, Nguyen Thanh Luan, 22 June 2019, BV 381 (VNM 00023642) (VNM!).

AcKnowledgments. The authors appreciate the contributions of Mr. Nguyen Thanh Luan (Asian turtle program of Indo-Myanmar Conservation) who kindly provided the photos and field data of Corybas himalaicus and C. geminigibbus.

\section{LiTERATURE CITED}

Averyanov, L.V., Phan, K. L. \& Nong, V. D. (2007). Corybas annamensis an important addition to the orchid flora of Eastern Indochina. Orchideen Journal, 14, 97.

Beentje, H. (2012). The Kew Plant Glossary, an illustrated dictionary of plant terms (revised edition). Royal Botanic Gardens, Kew: Kew Publishing.

Chantanaorrapint, S. \& Chantanaorrapint, A. (2016). Corybas geminigibbus (Orchidaceae), a new species record for Thailand. Thai Forest Bulletin (Botany), 44 (1), 11-14.

Chung, S. W. \& Hsu, T. C. (2008). Corybas himalaicus (King \& Pantl.) Schltr. (Orchidaceae): A Newly Recorded Species in Taiwan. Taiwan Journal of Forest Science, 23 (1), 99-103. 


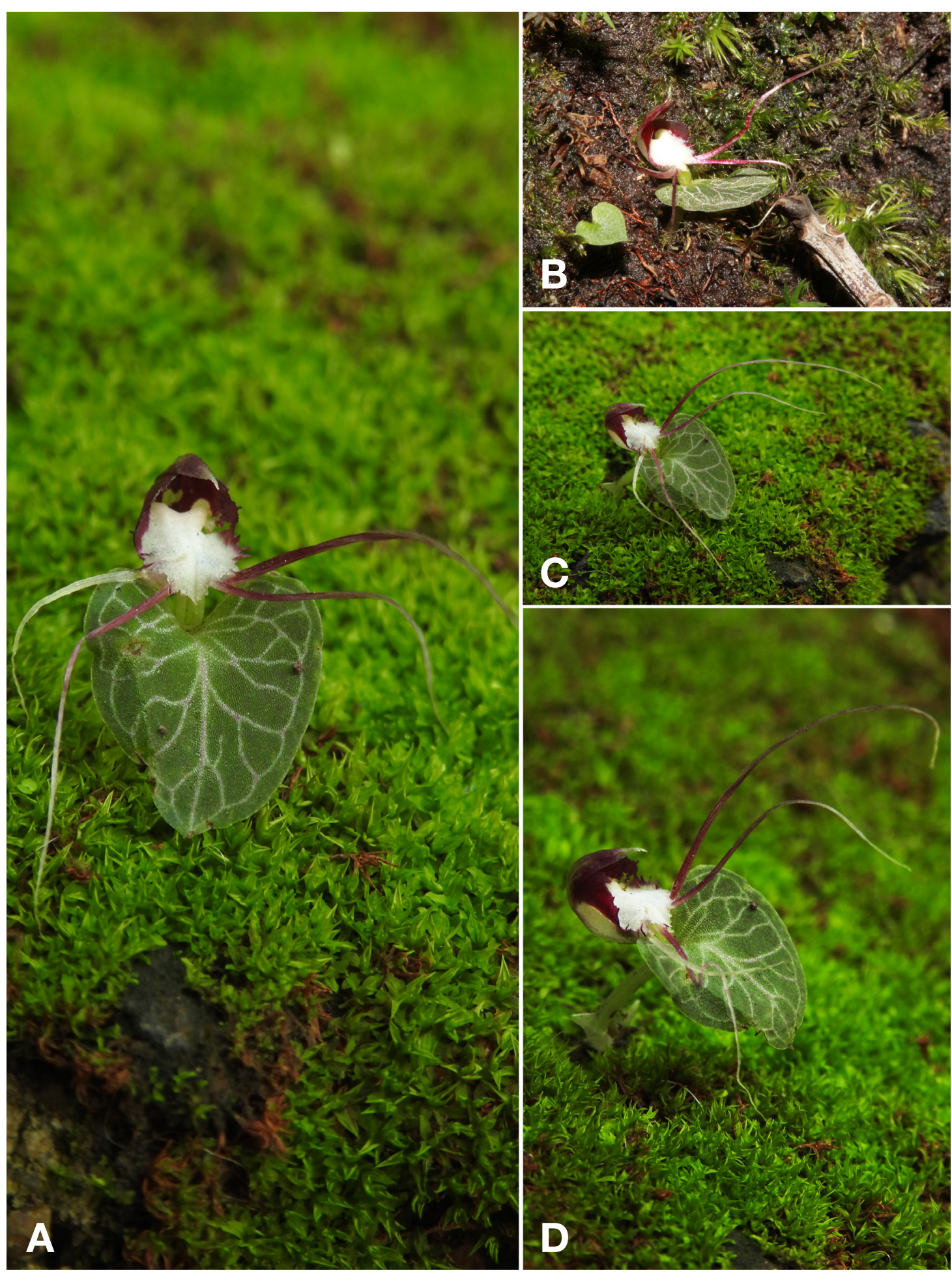

Figure 3. Corybas geminigibbus J.J.Sm. A-D. Plants in habitat showing morphological characters. Photographs by Nguyen Van Canh (A, C, D), and Truong Quang Cuong (B). 
Dransfield, J., Comber, J. B. \& Smith, G. (1986). A synopsis of Corybas (Orchidaceae) in west Malesia and Asia. Kew Bulletin, 41 (3), 575-613.

Govaerts, R., Bernet, P., Kratochvil, K, Gerlach, G., Carr, G., Alrich, P., Pridgeon, A. M., Pfahl, J., Campacci, M. A., Baptista, D. H., Tigges, H., Shaw, J., Cribb, P., George, A., Kreuz, K. \& Wood, J. (2019). World Checklist of Orchidaceae. Facilitated by the Royal Botanic Gardens, Kew.

Pearce, N. R. \& Cribb, P. J. (2002). The orchids of Bhutan Volume 3, Part 3. Royal Botanic Garden Edinburgh, Kew and Royal Government of Bhutan.

Pridgeon, A. M., Cribb, P. J., Chase, M. W. \& Rasmussen, F. N. (eds). (2001). Genera Orchidacearum Volume 2: Orchidoideae (Part one). Oxford: Oxford University Press.

Salisbury, R. A. (1807). LXXXIII Corybas aconitiflorus. In: R. A. Salisbury, W. Hooker \& D. D. Shury (Eds.), The paradisus londinensis or coloured figures of plants cultivated in the vicinity of the metropolis (t. 83). London: W. Hooker.

Seidenfaden, G. \& Wood, J. J. (1992). The Orchids of Peninsular Malaysia and Singapore. Fredensborg: Olsen \& Olsen. 
